\title{
Progress and Constraints to Achieving the MDGs in Africa
}

\author{
Hakim Ben Hammouda
}

Chief Economist and Special Representative of Executive Secretary of UNECA

\section{Progress and Constraints to}

\section{Achieving the MDGs in Africa}

\section{Hakim Ben Hammouda}

Chief Economist

United Nations Economic Commission for Africa, Addis Ababa, Ethiopia. 


\section{Structure of presentation}

$\checkmark$ Recent performance of African economies growth remains volatile and low relative to the level needed to achieve the MDGs

$\checkmark$ Progress towards achieving the MDGs

$\checkmark$ Constraints to growth acceleration in Africa

$>$ Internal constraints

$>$ External constraints

Strategies to overcome constraints to growth and speed up progress toward the MDGs

Overall Strong Performance in Africa in 2006 and the previous few years

Figure 1: Africa sustains improved overall economic performance (5.7\%), up from 5.3\% in 2005 and $5.2 \%$ in 2004

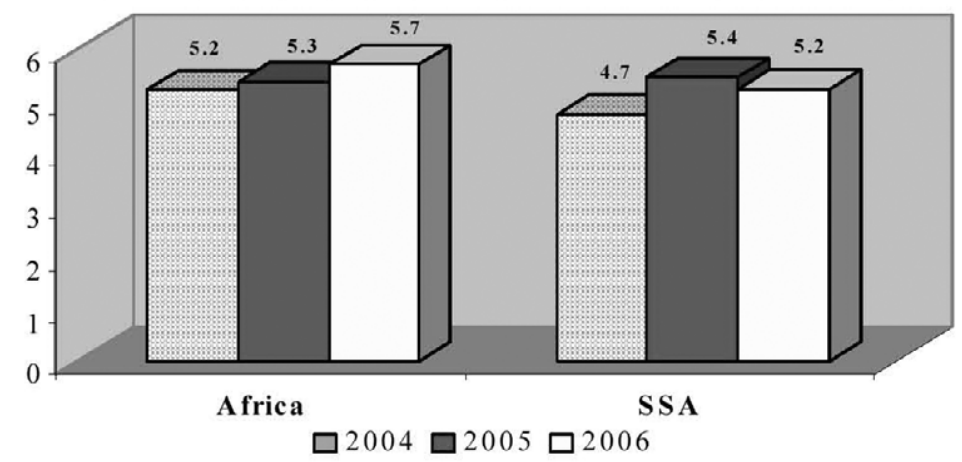




\section{Factors explaining recent economic performance in Africa}

1) Global economy: Strong global demand for key African export commodities, resulting in high export prices, especially for crude oil, metals and minerals.

2) Improvement in macroeconomic management in many countries

> Improved domestic balances, but pressure from oil prices threatens price stability

> Overall external balances remain stable

> Sustainability of both internal and external balances is a major challenge for oil importers and landlocked countries

3) Debt relief and external capital flows, especially ODA and FDI

\section{Factors explaining recent economic performance in Africa (cont'd)}

4) Strong performance in key sectors:

$>$ Agriculture remains the main driver of growth in many countries; increased value added through agriculture-related activities such as horticulture (e.g. Kenya and Ethiopia)

$>$ Tourism is an important source of foreign exchange earnings in many countries (South Africa, Egypt and Morocco)

$>$ Industry is still resource-based

> The service sector is large, growing, but remains fragile.

5. Increased political stability (decline in conflicts) in some countries contributed to growth. 
Figure 2: Oil economies sustain high growth rates in $2006(6.1 \%)$ as in 2005, while non-oil economies increased growth from $4.6 \%$ in 2005 to $5.2 \%$ in 2006 .

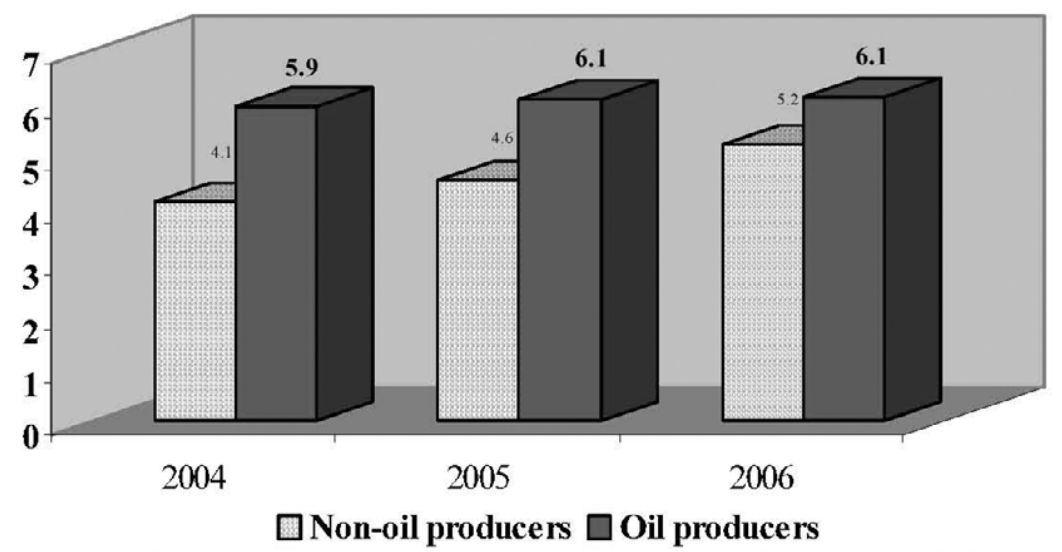

Figure 3: Non-oil non-mineral-rich countries grew even faster than mineral-rich non-oil countries thanks to debt relief, aid flows, and improved macroeconomic management, among other factors

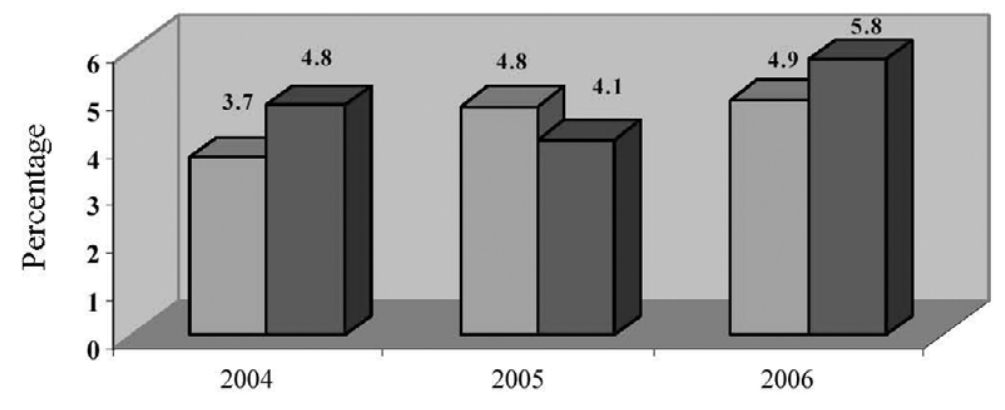

$\square$ Non-oil Mineral-rich countries $\square$ Non-Oil Non-Mineral Countries 
Despite improvement, Africa's growth is insufficient to meet its development goals

Table 1: Summary of growth performance over 19982006

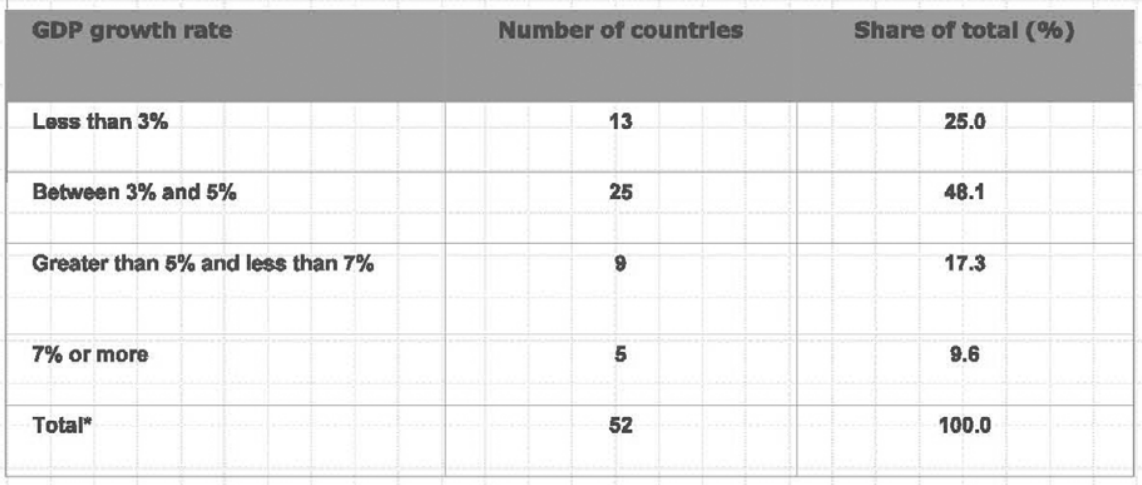

Slow progress towards the MDGs especially in SSA

Poverty rate remained virtually unchanged in SSA since 1990 (44.6\% in 1990 and $44 \%$ in 2004)

Primary enrollment and literacy rates rose from $53 \%$ and $67.4 \%$ to $64 \%$ and $73.1 \%$ in SSA and $81 \%$ and $66 \%$ to $94 \%$ and $84 \%$, respectively.

Gender equality improved: the gender parity ratio increased from 0.8 to 0.88 for SSA and from 0.73 to 0.91 for NA.

Child and maternal mortality remain high

$\checkmark$ HIVIAIDS and other pandemics remain a major challenge for Africa, calling for more budgetary allocations for prevention and treatment

More needs to be done for Africa to improve access to sanitation and safe water and to ensure environmental sustainability. 


\section{Table 2: Good progress toward the MDGs in NA, but disappointing progress in SSA}

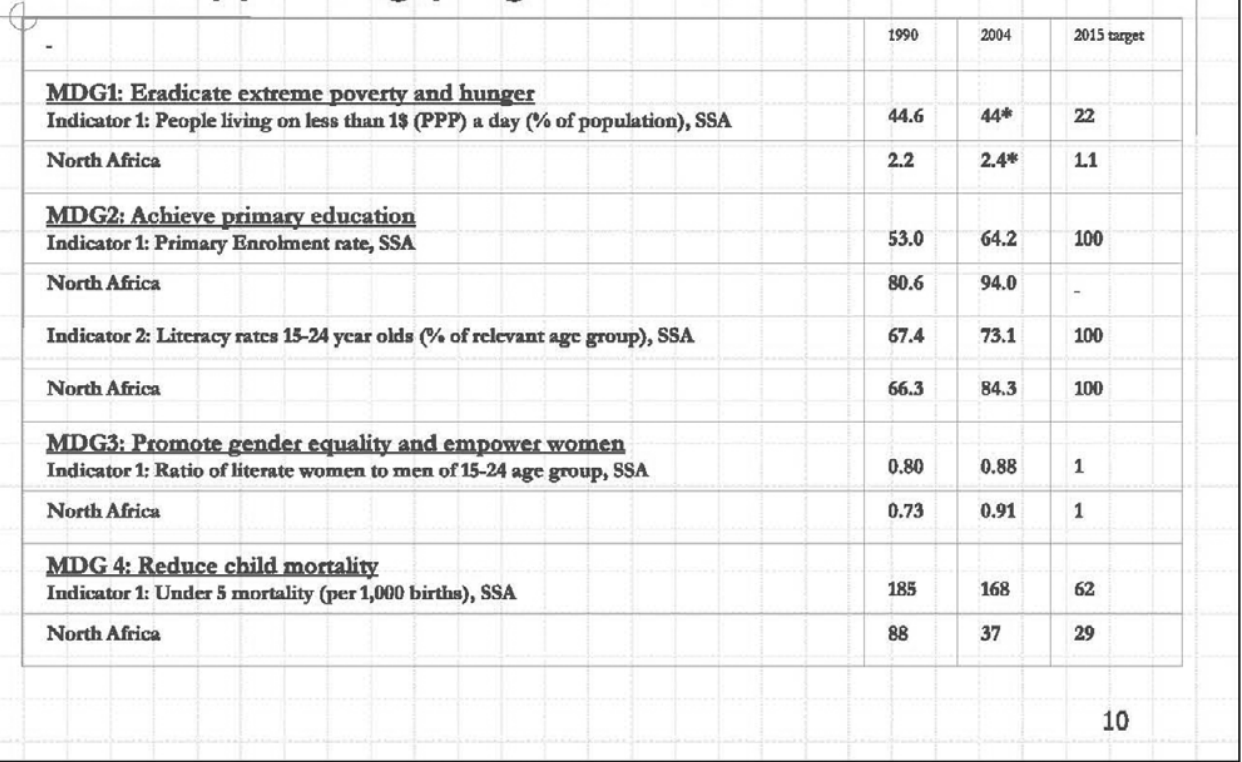

\section{Table 2 cont'd}

\begin{tabular}{|c|c|c|c|}
\hline - & 1990 & 2004 & 2015 target \\
\hline $\begin{array}{l}\text { MDG5: Reduce Maternal Mortality } \\
\text { Indicator 2: Proportion of deliveries attended by skilled health workers, SSA }\end{array}$ & 42 & 46 & 100 \\
\hline North Africa & 40 & 71 & 100 \\
\hline $\begin{array}{l}\text { MDG 6: Combat Malaria, Tuberculosis, HIV-Aids } \\
\text { Indicator 1: HIV/AIDS prevalence, SSA }\end{array}$ & 2.7 & $5.8 * \%$ & - \\
\hline North Africa & $<0.1$ & $0.1 * *$ & - \\
\hline $\begin{array}{l}\text { MDG7: Ensure environmental sustainability } \\
\text { Indicator 1: Proportion of land area covered by forest, SSA }\end{array}$ & 29.2 & 26.5 & - \\
\hline North Africa & 1.3 & 1.5 & - \\
\hline Indicator 2: Access to improved sanitation ( $\%$ of population), SSA & 32 & 37 & 66 \\
\hline North Africa & 65 & 77 & 83 \\
\hline $\begin{array}{l}\text { MDG8: Develop a Global Partnership for development } \\
\text { Indicator 1: Share of ODA flows (\% of donor GNI) }\end{array}$ & 0.33 & 0.2 & 0.7 \\
\hline
\end{tabular}

Notes: * Data for 2002, ** Data for 2005 


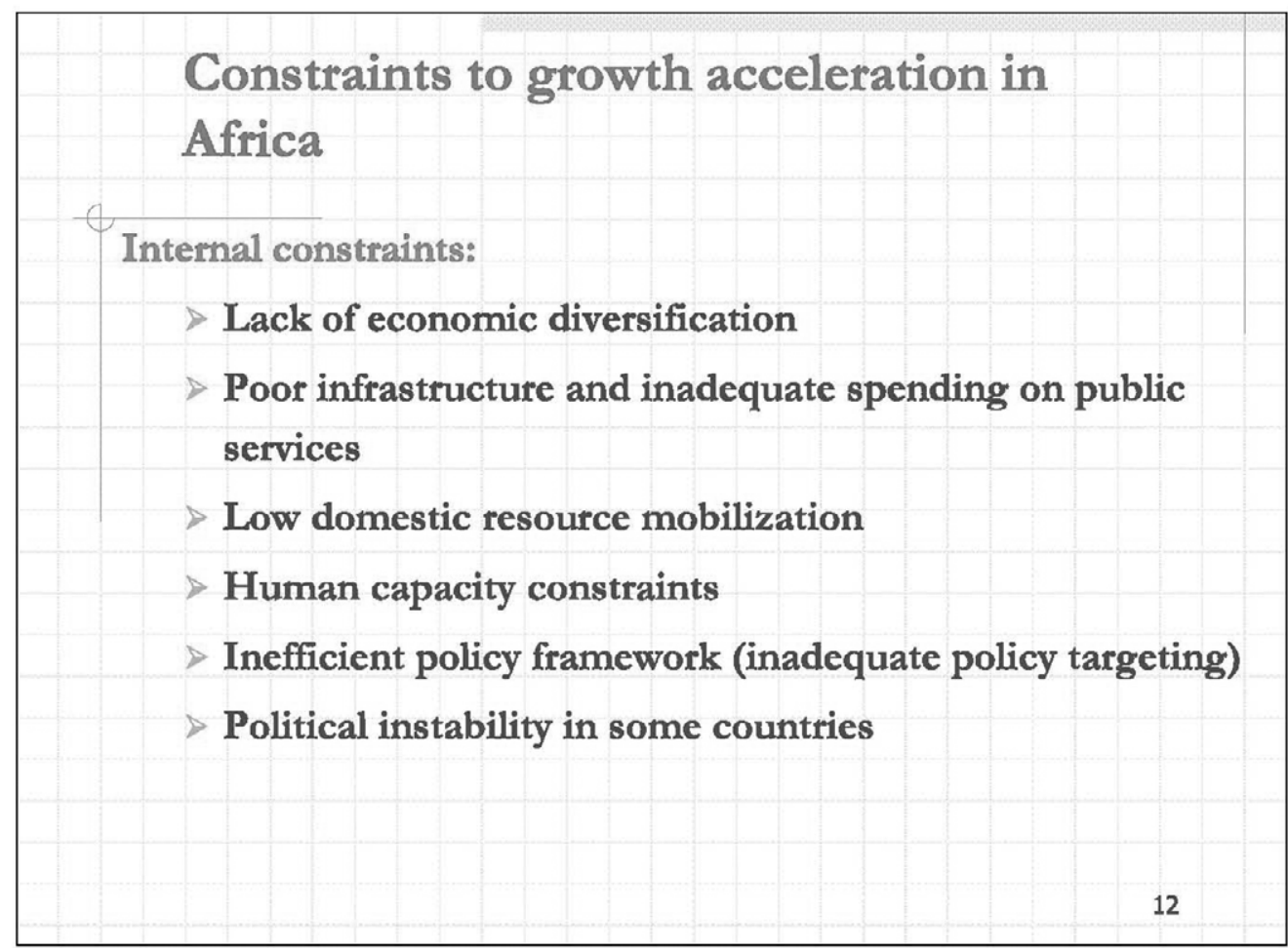

External constraints:

Lack of market access for African exports

Aid levels still insufficient and limited efficiency in the use of aid

Debt cancellation not enough and external debt burden seriously constrains development financing

$>$ Weather shocks and developments in the global economy cause fluctuations in commodity demand and prices, resulting in instability of export revenue. 


\section{Policy recommendations}

Africa needs to increase and sustain growth to accelerate social development through:

Diversification away from resource sectors and promoting international compositeness

Improved macroeconomic management and business climate

Increased domestic investment which requires mobilization of internal and external resources including grants, FDI and debt relief

\section{Policy recommendations contd.}

4. Improved infrastructure (especially transport and energy supply) and human capital base

5. Adoption of a more innovative approach to growth and pro-poor policies

6. Fighting HIVIAIDS and other pandemics 